\title{
Microsatellite Analysis of Population Structure in the Endangered Hawaiian Monk Seal
}

\author{
MARIA B. KRETZMANN, ${ }^{*} \dagger \ddagger$ NEIL J. GEMMELL, $\neq ₫$ AND AXEL MEYER $† * *$ \\ *Department of Biology, University of California, Santa Cruz, CA 95064, U.S.A. \\ †Department of Ecology and Evolution, State University of New York, Stony Brook, NY 11794, U.S.A. \\ ‡Department of Zoology, University of Cambridge, Downing Street, Cambridge CB2 3EJ, United Kingdom \\ §Department of Zoology, University of Canterbury, P.O. Box 4800, Christchurch, New Zealand \\ ${ }^{* *}$ Department of Biology, University of Konstanz, 78457 Konstanz, Germany
}

\begin{abstract}
The endangered Hawaiian monk seal breeds at six locations in the northwestern Hawaiian Islands. To determine whether significant genetic differentiation exists among these sites, we used microsatellite loci to examine the monk seal population structure at the five largest breeding colonies. Of 27 loci isolated from other seal species, only 3 were polymorphic in an initial screening of one individual from each breeding site. Only two alleles were found at each of these 3 loci in samples of 46-108 individuals. This extremely low variation is consistent with other measures of genetic variability in this species and is probably the result of a recent severe population bottleneck, combined with a long-term bistory of small population sizes. Although the smallest monk seal subpopulation in this study (Kure Atoll) showed some evidence of beterozygote deficit, possibly indicative of inbreeding, the next smallest (Pearl and Hermes Reef) had an apparent excess of heterozygous individuals. Genetic differentiation was detected between the two subpopulations at extreme ends of the range (Kure and French Frigate Shoals). This trend was significant only at the microsatellite locus for which we had the largest sample size (Hg6.3: $\mathrm{R}_{\mathrm{ST}}=0.206, \mathrm{p}=0.002$; allelic goodness of fit $\left.\mathrm{G}_{\mathrm{h}}=15.412, \mathrm{p}<0.005\right)$. French Frigate Shoals is the source population for translocated animals that have been released primarily at Kure Atoll. Differentiation between these sites consisted of allele frequency differences (with the same allele predominant in each location at all three loci), rather than the preservation of alternative alleles. Although the translocations have had positive demographic effects, we recommend continued genetic monitoring of both the source and recipient populations because translocated individuals are now entering the breeding population.
\end{abstract}

Análisis Microsatélite de la Estructura Poblacional de la Foca Monje de Hawai

Resumen: La foca monje de Hawai está en peligro y se reproduce en seis localidades del noroeste de las islas de Hawai. Para determinar la existencia de diferencias genéticas significativas entre estos sitios, examinamos la estructura de la población de focas monje en las cinco colonias reproductivas más grandes mediante loci microsatélites. De 27 loci aislados de otras especies de focas, solo tres fueron polimórficos en un muestreo inicial en un individuo de cada colonia. Solo dos alelos fueron encontrados en cada uno de estos tres loci en muestras de 46-108 individuos. Esta variación extremadamente baja es consistente con otras medidas de variabilidad genética en esta especie, y probablemente sea el resultado de un cuello de botella severo y reciente combinado con una larga bistoria de poblaciones pequeñas. Aunque la subpoblación más pequeña de este estudio (Atolón Kure) mostró ciertas evidencias de déficit de beterocigosidad, lo que indica posible endogamia, la siguiente más pequeña (Arrecife Pearl y Hermes) tenía un exceso aparente de individuos beterocigóticos. Se detectó diferenciación genética entre dos subpoblaciones en los extremos del rango (Bancos Kurs y French Frigate). Esta tendencia solo fue significativa en el locus microsatélite (Hg6.3) del que se obtuvo el mayor tamaño de muestra $\left(\mathrm{R}_{\mathrm{ST}}=0.206, \mathrm{p}=0.002 ;\right.$ bondad de ajuste alélica $\left.\mathrm{G}_{\mathrm{h}}=15.412, \mathrm{p}<0.005\right)$. El Banco French Frigate es la población originaria de los animales translocados que se ban liberado principalmente en el Atolón Kure. La diferenciación entre estos sitios consistió en frecuencias alélicas distintas (con el

¥¥Address for correspondence: 220 Pipe Stave Hollow Road, Mt. Sinai, NY 11766, U.S.A., email kretzman@life.bio.sunysb.edu Paper submitted February 4, 1999; revised manuscript accepted June 28, 2000. 
mismo alelo predominante en cada localidad en los tres loci), y no en la preservación de los alelos alternativos. Aunque las translocaciones ban tenido efectos demográficos positivos, recomendamos continuidad en el monitoreo genético de las poblaciones fuente y vertedero debido a que los individuos translocados están entrando a la población reproductora.

\section{Introduction}

The endangered Hawaiian monk seal was hunted to near extinction in the nineteenth century (Kenyon \& Rice 1959), although the size and duration of this population bottleneck are not well documented. The species currently breeds at six principal locations in the northwestern Hawaiian islands (Westlake \& Gilmartin 1990; Fig.1). Following partial recovery in the first half of this century, the populations at five of these sites (Kure Atoll, Midway Atoll, Pearl and Hermes Reef, Lisianski and Laysan islands) decreased dramatically between the 1950s, when the first reliable surveys were made, and the 1970s (Johnson et al. 1982; Gilmartin \& Eberhardt 1995). These declines have been attributed at least partially to human disturbance at breeding rookeries (Kenyon 1972; Gerrodette \& Gilmartin 1990). Although an increase in population size occurred at French Frigate Shoals during this time, the overall number of individuals was approximately halved and has since declined further, from about 3000 to a current estimate of 1300-1400 seals (Johnson et al. 1982; Ragen 1993).

At Kure Atoll and Pearl and Hermes Reef, population sizes may have been reduced to fewer than 50 seals (Johnson et al. 1982; Gilmartin \& Eberhardt 1995), of which probably only a small fraction were breeding adults. Generally, the monk seal shows a high degree of site fidelity, and movements occur most often among ad- jacent islands (Johnson \& Kridler 1983). Although about $10 \%$ of tagged seals have been sighted at locations other than their natal islands by age 10 (Ragen 1993), the percentage of those migrants entering the breeding population is not known. Therefore, the combined effects of random genetic drift and inbreeding are likely to have led to low genetic variation within these small subpopulations, and perhaps significant differentiation among some breeding sites.

The monk seal has been shown to be depauperate in genetic variation, based on both mitochondrial and nuclear DNA markers (Kretzmann et al. 1997), but the question of whether significant genetic differentiation exists among the principal monk seal subpopulations has not yet been resolved. In one case, a rare mtDNA control region haplotype was observed on four of the five main islands, supporting the idea of a panmictic population (Kretzmann et al. 1997). In contrast, multilocus DNA fingerprint profiles of seals from two adjacent island pairs showed significantly higher bandsharing values among individuals within sites than among those between sites, yielding significant $F_{S T}$ estimates of 0.13 (for Lisianski and Laysan) to 0.20 (for Kure and Pearl and Hermes Reef) (Kretzmann et al. 1997). The extent of subpopulation differentiation in the monk seal is of particular interest because of a translocation program in effect from 1985 to 1995 . This program involved rehabilitating undersized weaned females from the largest

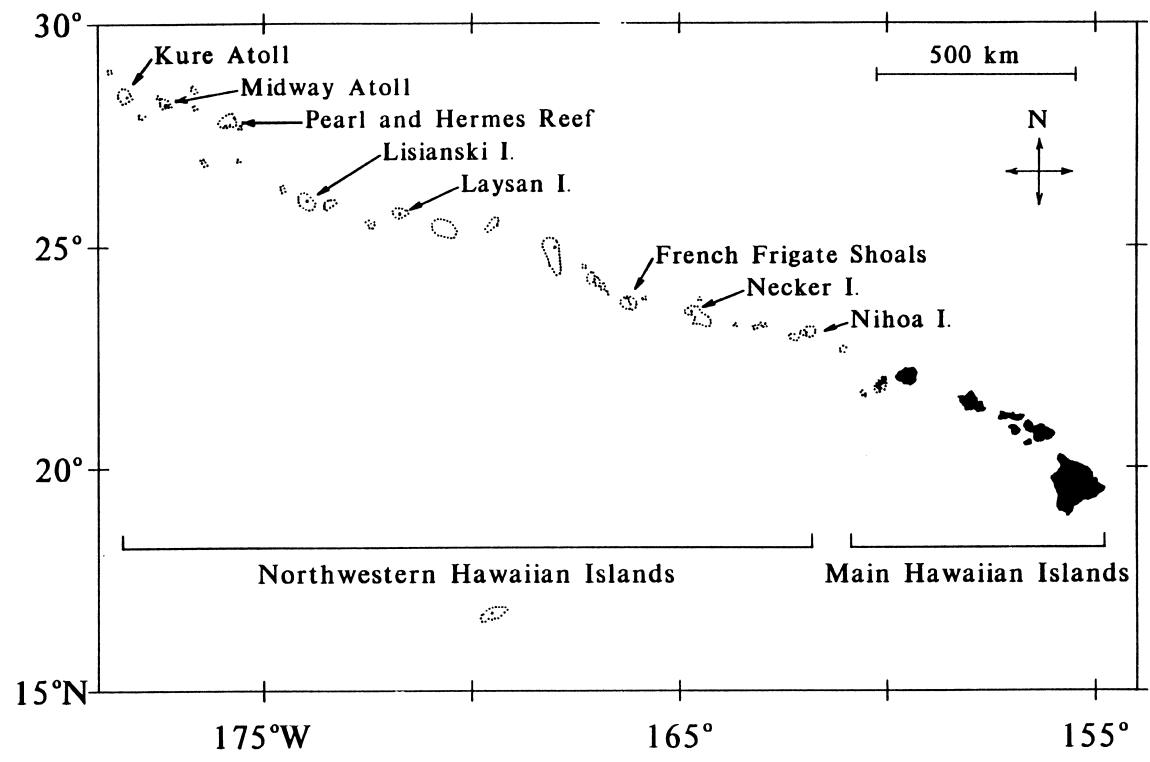

Figure 1. Map of the nortbwestern Hawaiian islands (from Ragen [1993], with permission). The current principal breeding sites of the Hawaiian monk seal are Kure Atoll, Midway Atoll, Pearl and Hermes Reef, Lisianski Island, Laysan Island, and French Frigate Shoals. 
rookery at French Frigate Shoals and releasing them at other locations (primarily Kure Atoll) where the probability of survival might be enhanced by greater food availability (Gerrodette \& Gilmartin 1990; Van Toorenburg et al. 1993).

We attempted to address the extent of genetic differentiation among five monk seal subpopulations using microsatellite DNA analysis. This type of molecular marker consists of tandemly repeated sequence units of $1-5 \mathrm{bp}$ scattered throughout eukaryotic genomes; it is often highly polymorphic due to variation in repeat copy number and can be assessed in samples of poor quality (degraded DNA) by means of the polymerase chain reaction (Tautz 1989; Weber \& May 1989). Analysis of microsatellite loci has effectively resolved population structure even in species with relatively low genetic variation as measured by other techniques (e.g., Paetkau \& Strobeck 1994; Taylor et al. 1994; Petit et al. 1997). This approach therefore seemed particularly well suited to the study of population structure in the Hawaiian monk seal. Variability in this species is known to be low, and the remoteness of the field sites and sensitivity of the populations to disturbance precludes obtaining many samples of highquality DNA (Kretzmann et al. 1997).

\section{Methods}

\section{Sample Collection}

Tissue samples $(n=108)$ were obtained from monk seal flippers during tagging operations between 1987 and 1994. Two additional samples were obtained from necropsies. These samples represented five subpopulations approximately equally: 20 from Kure Atoll, 18 from Pearl and Hermes Reef, 25 from Lisianski Island, 23 from Laysan Island, and 24 from French Frigate Shoals (see Fig.1). Few pups were born at Midway Atoll during the sampling period, and this site was not included. Within each island or atoll, samples were collected from all pupping sites, primarily from pups of the year $(n=98)$. A few samples from older animals (nine juvenile and three subadult or adult) were also included. Because several different cohorts of pups were included in each island's sample, at some locations the inclusion of some half-siblings was unavoidable if reasonable sample size was to be attained. Some full siblings may even be included, if one or a few male(s) are able to dominate breeding at a specific location over a period of several years. The degree of polygyny in the monk seal is unknown and may vary by location, perhaps depending on island topography.

\section{Identification of Microsatellite Loci}

Recently, 20 microsatellite primer sets derived from other seal species were tested on a panel of five Hawai- ian monk seals, one from each of the principal subpopulations; they revealed only three polymorphic loci in this species (Gemmell et al. 1997). An additional 7 primer sets derived from the harbor seal (Phoca vitulina), shown to amplify polymorphic microsatellite loci in other pinnipeds (Coltman et al. 1996), were also evaluated for use in the monk seal, but all of these proved monomorphic in the five individuals tested (N.J. Gemmell, unpublished data). Of the three loci that were polymorphic in the Hawaiian monk seal sample, only locus Hg6.3 (derived from the grey seal [Halichoerus grypus]; Allen et al. 1995) was uncomplicated to analyze, and we focused our efforts on typing as many individuals as possible for this locus. We obtained more limited data from the other two polymorphic microsatellites. Locus Pv17 (from the harbor seal; Goodman 1997a) appears to be X-linked in all pinnipeds (Gemmell et al. 1997), and analysis was therefore limited to females. Primers for locus BG (a pentanucleotide microsatellite from the southern elephant seal [Mirounga leonina]; R. Slade, unpublished data) amplify at least two loci in all pinnipeds tested (Gemmell et al. 1997).

\section{DNA Extraction and Amplification of Microsatellites}

The DNA was extracted from tissue samples following standard protocols (Maniatis et al. 1989). For microsatellite amplification via the polymerase chain reaction (PCR), we used reverse primers labeled with tetrachloro-6-carboxyfluorescein (TET). Each $15 \mu \mathrm{L}$ reaction consisted of $8.925 \mu \mathrm{L} \mathrm{ddH_{2 }} \mathrm{O}, 1.5 \mu \mathrm{L}$ 10X PCR buffer (10 $\mathrm{mM}$ Tris- $\mathrm{HCl}, 50 \mathrm{mM} \mathrm{KCl}, 1.5 \mathrm{mM} \mathrm{MgCl} 2$ ), $0.9 \mu \mathrm{L} \mathrm{MgCl}_{2}$ ( $25 \mathrm{mM}$; to bring final concentration to $3 \mathrm{mM}$ ), $0.6 \mu \mathrm{L}$ dNTPs $(10 \mathrm{mM}), 0.8 \mu \mathrm{L}$ each of forward and reverse primers $(10 \mu \mathrm{M}), 0.375 \mu \mathrm{L}$ formamide, $0.10 \mu \mathrm{L}$ Taq polymerase, and approximately $20 \mathrm{ng}$ genomic DNA. Reaction conditions were as follows: $2 \mathrm{~m}$ at $94^{\circ} \mathrm{C}$, then 8 cycles of 30 seconds at $94^{\circ} \mathrm{C}, 30$ seconds at $48^{\circ} \mathrm{C}, 40$ seconds at $72^{\circ} \mathrm{C}$, and finally 32 cycles of 15 seconds at $94^{\circ} \mathrm{C}, 15$ seconds at $52^{\circ} \mathrm{C}, 40$ seconds at $72^{\circ} \mathrm{C}$. The relatively low initial annealing temperature was designed to allow for potential primer mismatches, as recommended by Pemberton et al. (1995) to minimize the occurrence of nonamplifying (null) alleles.

\section{Cloning and Sequencing of Locus Hg6.3}

Because the primers we used were derived from other seal species, we wanted to verify that a homologous microsatellite was amplified in the Hawaiian monk seal for the locus we investigated most thoroughly (Hg6.3; Allen et al. 1995). Because this locus is a pure (uninterrupted) microsatellite in the focal species, the grey seal, we also wanted to check for the presence of imperfections in the monk seal repeat sequence, which might affect the stability of the locus in this species (Goldstein \& Pollock 
1997). Accordingly, we cloned an aliquot of the PCR product from an Hawaiian monk seal amplification using Hg6.3 primers with the pGEM-T vector (Promega) in $E$. coli SURE cells, following the manufacturer's instructions. We mini-prepped positive colonies to recover plasmid DNA using the Wizard DNA purification system (Promega), and the presence of the insert was verified by restriction digest and visualization on an agarose gel with ethidium bromide. Microsatellite DNA was then purified for sequencing by ethanol precipitation, and a cycle sequencing reaction was carried out by the Taq Dye Deoxy Terminator (Applied Biosystems) protocol and M13 universal sequencing primers. The sequence was determined with an Applied Biosystems 373A automated sequencer and associated analysis software.

\section{Microsatellite Analysis}

The PCR products were visualized on agarose gels stained with ethidium bromide. Strong amplifications were diluted 1:10, and weak amplifications were used undiluted. One microliter of each sample was then mixed with $2 \mu \mathrm{L}$ formamide and $0.5 \mu \mathrm{L}$ each of the size standard (GeneScan TAMRA-500, Applied Biosystems) and the TAMRA buffer. This mixture was denatured at $95^{\circ} \mathrm{C}$ for 2 minutes and loaded on 5\% "Sequagel" (National Diagnostics) with $1 \mathrm{X}$ TBE buffer in the Applied Biosystems 373A automated sequencer. Allele sizes were given by the GeneScan software, based on comparison of migration distances with those for the TAMRA fragments of known size within each lane, making comparisons among gels possible.

\section{Statistical Analysis}

We performed analysis of subpopulation differentiation using $R_{S T}$ Calc (version 2.2; Goodman 1997b). This software is based on Slatkin's (1995) measure of genetic differentiation and was designed to account for some features of microsatellite evolution, with corrections for differences in sample size among populations and differences in allele size variance among loci. This program assesses the significance of the $R_{S T}$ and $N_{m}$ estimates through permutation tests (Goodman 1997b). To facilitate comparison with other studies, we obtained $F_{S T}$ estimates (Weir \& Cockerham 1984) using the computer program GENEPOP, version 2 (Raymond \& Rousset 1995). We also used the allelic goodness-of-fit test (Sokal \& Rohlf 1995) for population differentiation, as recommended by Goudet et al. (1996) for having the most statistical power when sampling is unbalanced. The GENEPOP program was also used to perform exact tests for deviations from Hardy-Weinberg equilibrium (Louis \& Dempster 1987) and tests for significant heterozygote deficit and excess, based on the Markov chain method of Guo and Thompson (1992). The sequential Bonfer- roni correction for multiple tests was applied to all estimates of statistical significance (Rice 1989).

\section{Results}

We obtained genotypes for 108 individuals at locus Hg6.3 and about half that number for the other two loci, Pv17 ( $n=45)$ and BG ( $n=51)$; at each locus we found only the two alleles previously identified in a sample of five individuals by Gemmell et al. (1997). Due to the different scoring methods employed (Gemmell et al. scored allele sizes manually by comparison with a sequencing reaction), the precise allele sizes we recorded varied slightly from those reported previously (Table 1; see also Schwengel et al. 1994).

For locus $\mathrm{Hg} 6.3$, the results of the cloning and sequencing confirmed that we were in fact scoring a microsatellite locus in the Hawaiian monk seal that was analogous to the original one isolated from a grey seal library (Allen et al. 1995). The alignment of the flanking regions from the two species showed differences of 5-7\%, but some of these may be attributable to PCR sequencing artifacts because even the grey seal primer sequences in our analysis differed by at least two base pairs from the original sequences (Fig. 2). The apparent length of the monk seal allele we sequenced was 227 bp (Fig. 2), which is within the size range reported for grey seals by Allen et al. (1995). It is also within 2 bp of both our estimate from the GeneScan software and Gemmell et al.'s (1997) estimate based on manual scoring by comparison with a sequencing reaction (Table 1). Although this indicates that precise allele sizes may not be reliably recorded by one or both methods, we assumed that the relative sizes of alleles were correctly identified.

Exact probability tests for Hardy-Weinberg equilibrium (Louis \& Dempster 1987) revealed no significant deviations for any combination of locus and population (all $p$ values $>0.17$; Appendix). At each locus, the same

Table 1. Allele sizes (in base pairs) for Hawaiian monk seals at three microsatellite loci, as reported by Gemmell et al. (1997) ${ }^{a}$ and as measured in the current study. ${ }^{b}$

\begin{tabular}{lcccc}
\hline Locus $^{c}$ & Gemmell et al. & (1997) & \multicolumn{2}{c}{ Current study } \\
\hline Hg6.3 & 225 & 231 & 229 & 239 \\
Pv17 & 146 & 148 & 144 & 146 \\
BG1 $^{d}$ & 259 & 284 & 262 & 285 \\
BG2 & 309 & 314 & 309 & 314 \\
\hline
\end{tabular}

${ }^{a}$ Based on manual scoring by comparison with a sequencing reaction.

${ }^{b}$ Based on fluorescent primers and the GeneScan software.

${ }^{c}$ The $\mathrm{Hg} 6.3$ and $P v 17$ are dinucleotide repeats, and BG represents two linked loci of pentanucleotide repeats.

${ }^{d}$ The smaller allele at BG1 always occurred with the smaller allele at BG2. Only BG1 was used to represent BG because it amplified more strongly than BG2. Gemmell et al.'s (1997) sizes were used because they differ by a factor of five. 
CACTACACTG CACAGTGCCA TTCCAGGGG TCCATCTACT TCTGTGTGTC ATACAGGGGA ......

CCTGAGTGCT TATGAAATA ATTTTGTGAG TCTCAACTTG CATTAGACAG TGCAAAATAG

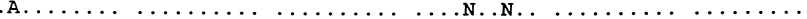

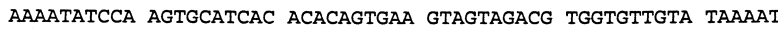

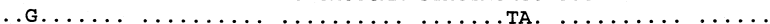

microsatellite: $\mathrm{GT}_{17}$ (grey seal clone)

$\mathrm{GT}_{18}$ (monk seal clone)

CGCAGCATCA TATAACGTCT GGGAGCACAG ACTCTGGAGC CAGATTACTT GAGTTCTGAT

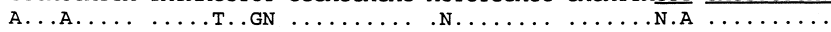

GCTGGGTCTG CCGTTGGG

Figure 2. Alignment of flanking regions for microsatellite locus Hg6.3 isolated from the grey seal (Allen et al. 1995; sequence shown on top, primer annealing points underlined), with the bomologous locus cloned and sequenced in the Hawaiian monk seal (sequence differences and unresolved sequence [N] shown below the grey seal sequence). Dots denote equivalent sequence.

allele was most common in each of the subpopulations. Frequencies of the more common allele varied among subpopulations, but no consistent pattern across loci was observed (Fig. 3; Appendix). The percentage of heterozygous individuals did appear to vary consistently, however, with Kure having the lowest and Pearl and Hermes having the highest percentage for all three loci (Fig. 3). Exact probability tests for heterozygote deficit and excess using all three loci showed a heterozygote deficit in the Kure subpopulation. Pearl and Hermes Reef had an excess, although these departures from Hardy-Weinberg equilibrium were not statistically significant after sequential Bonferroni correction for multiple tests (Rice 1989; Table 2).

The allele frequency differences among islands at these three microsatellite loci (Fig. 3, Appendix) yielded an overall estimate of genetic differentiation $\left(R_{S T}\right)$ of 0.037 among the five subpopulations (Table 3 ). This value would correspond to an estimated 6.5 migrants per generation among these islands at equilibrium ( $\mathrm{Ta}$ ble 3). Because the variation detected at these microsatellite loci was limited to two alleles each, overall $R_{S T}$ estimates were nearly identical to $F_{S T}$ values calculated according to Weir and Cockerham (1984) (overall $F_{S T}=$ $0.038, p=0.008)$. When analysis was limited to locus Hg6.3, for which we have the most complete data set, support for subpopulation differentiation was strengthened $\left(R_{S T}=0.071, N m=3.3, p=0.002\right.$; Table 3). In contrast, the $R_{S T}$ value over all subpopulations for locus BG alone was negative, indicating a lack of differentiation at this locus. Locus Pv17 alone yielded an overall $R_{S T}$ value of 0.041 , which was not significantly different from zero (Table 3 ).
These results were confirmed by the allelic goodnessof-fit test, in which locus Hg6.3 supported significant differentiation among breeding sites $\left(G_{\text {heterogeneity }}=15.412\right.$, $p<0.005)$, whereas loci Pv17 $\left(G_{b}=8.431,0.10>P>\right.$ $0.05)$ and BG $\left(G_{b}=4.208,0.50>p>0.10\right)$ did not. To partition the total $G_{b}$ for locus $\mathrm{Hg} 6.3$ into contributions due to individual subpopulations, we followed the procedure described by Sokal and Rohlf (1995) and found that significant differentiation among sites at this locus was entirely attributable to allele frequency data from French Frigate Shoals. The other four islands did not differ significantly from one another (Kure + Pearl and Hermes + Lisianski + Laysan; $\left.G_{b}=1.243,0.90>p>0.50\right)$.

Inter-island differences were convincingly demonstrated only for a single pairwise comparison with the $R_{\mathrm{ST}}$ analysis. When all three loci were considered, 2 of 10 inter-island differentiation estimates had $p$ values of $<0.05$ (Table 3). Following sequential Bonferroni correction for multiple tests (Rice 1989), neither of these pairwise comparisons was significant. At locus $\mathrm{Hg} 6.3$, for which we have twice as many individuals typed as for the other two loci, French Frigate Shoals was significantly $(p=0.002)$ differentiated from both Kure and Laysan (Table 3). Only the Kure-French Frigate Shoals comparison was supported by a generally consistent pattern across all three loci (i.e., positive $R_{S T}$ values; Table 3).

\section{Discussion}

\section{Lack of Genetic Variation}

The most significant finding of our study is a remarkable lack of genetic variation at microsatellite loci in the Hawaiian monk seal. Gemmell et al. (1997) reached this conclusion based on the preliminary analysis of five Hawaiian monk seals tested with 20 primer sets. We have now extended their study by testing 7 additional primer sets and by examining 46-108 individuals at the three loci that showed some polymorphism in the preliminary analysis. No additional variation was found. Although this result is consistent with other measures of genetic variation in this species (Kretzmann et al. 1997), we are aware of no other species examined with similar sampling effort which revealed such low polymorphism at microsatellite loci.

Even among studies using cross-species primers (like ours), more variation was typically found at microsatellite loci. A sample of 29 individuals from one isolated island population of rock-wallabies showed variation at only 1 of 10 loci derived from other wallaby species, but larger mainland populations of the same species were highly variable at all 10 loci (Eldridge et al. 1999). A sample of 42 individuals from a population of mouflon sheep derived from 19 founders was shown to have polymorphic microsatellite loci with two to seven al- 

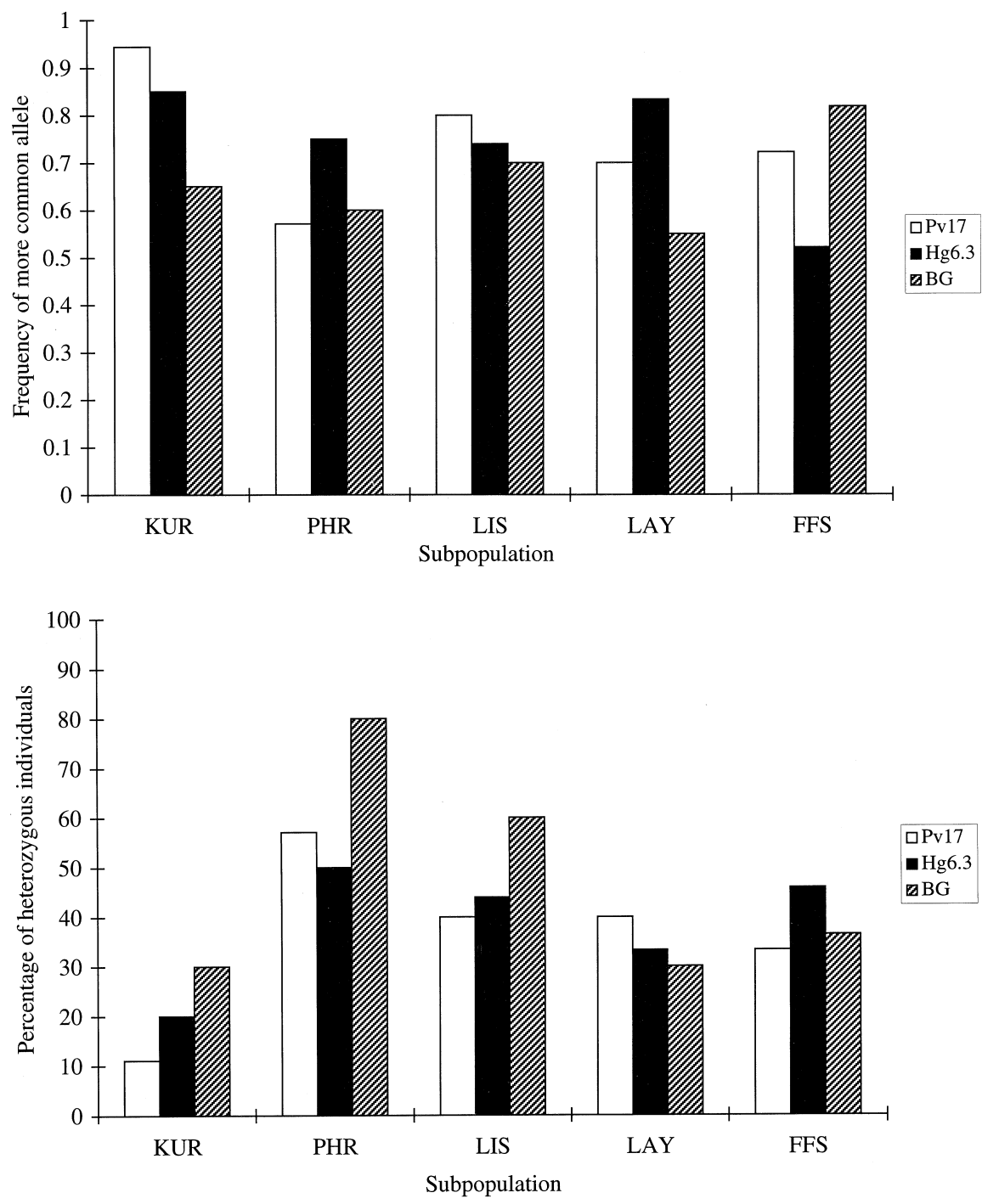

Figure 3. (top) Frequency of the more common of two alleles (the same allele at each locus in each subpopulation), and (bottom) percentage of heterozygous individuals at each of three microsatellite loci (Pv17, Hg6.3, and BG) in five subpopulations of the Hawaiian monk seal (KUR, Kure Atoll; PHR, Pearl and Hermes Reef; LIS, Lisianski; LAY, Laysan; FFS, French Frigate Shoals).

leles, with primers derived from cattle (Petit et al. 1997). Of 15 cattle primers tested in a sample of 34 muskoxen, 12 gave a PCR product but only 2 loci were variable, with two or three alleles. In this case, even less variation was revealed with 6 species-specific microsatellite primers (Holm et al. 1999).

Because the primers we used were derived from other seal species, we had to consider the possibility of ascertainment bias. Ellegren et al. (1995) and Goldstein and Pollock (1997) have argued that microsatellites will be longer and hence more variable in the focal species from which the primers were derived than in related species because they are selected for those attributes during the cloning process. We do not believe that the very low variation observed among Hawaiian monk seals can be attributed to such a bias. First, four individuals from a single population of the Mediterranean monk seal, a related and even more highly endangered species, showed variation at 12 of the 20 loci used in the initial screening (Gemmell et al. 1997). In addition, of the 20 original loci tested, in 10 cases the mean allele length in the focal species was in the top half of the range for all species, and in 10 cases it was in the bottom half (B. Amos et al., unpublished data). The cross-species amplification data set of Gemmell et al. (1997) therefore shows no evidence of ascertainment bias.

The extremely low variation observed in the Hawaiian monk seal is likely attributable to both the long-term evolutionary history of the species and to more recent human influences. The Hawaiian monk seal is thought to have occupied the Pacific for at least the last 3.5-4 million years (de Muizon 1982). During this time, all of the northwestern Hawaiian islands currently inhabited by this species were well established (Carson \& Clague 1995). Although sea-level changes would have periodically decreased the distances among these islands and exposed more of each island above water, continual erosion and subsidence of these islands (Carson \& Clague 1995) would have decreased the available coastal habitat required by the monk seal. Thus, these seals have proba- 
Table 2. Results of Hardy-Weinberg (HW) exact probability tests for heterozygote deficit and excess, performed as described by Guo and Thompson (1992) using GENEPOP (Raymond \& Rousset 1995). ${ }^{a}$

\begin{tabular}{|c|c|c|c|c|}
\hline & \multicolumn{2}{|c|}{$\begin{array}{l}\text { Heterozygote } \\
\text { deficit }\end{array}$} & \multicolumn{2}{|c|}{$\begin{array}{l}\text { Heterozygote } \\
\text { excess }\end{array}$} \\
\hline & $\mathrm{p}$ & $S E$ & $\mathrm{p}$ & $S E$ \\
\hline \multicolumn{5}{|l|}{$\begin{array}{l}\text { Subpopulation } \\
\qquad \text { (test across loci) }^{b}\end{array}$} \\
\hline KUR & 0.029 & 0.002 & 0.967 & 0.002 \\
\hline PHR & 0.983 & 0.001 & 0.018 & 0.002 \\
\hline LIS & 0.840 & 0.003 & 0.155 & 0.003 \\
\hline LAY & 0.340 & 0.004 & 0.662 & 0.005 \\
\hline FFS & 0.282 & 0.005 & 0.719 & 0.004 \\
\hline \multicolumn{5}{|l|}{$\begin{array}{l}\text { Locus (test across } \\
\text { subpopulations) }\end{array}$} \\
\hline Pv17 & 0.411 & 0.004 & 0.598 & 0.005 \\
\hline Hg6.3 & 0.679 & 0.005 & 0.316 & 0.006 \\
\hline BG & 0.692 & 0.005 & 0.299 & 0.004 \\
\hline $\begin{array}{l}\text { Over all loci and } \\
\text { subpopulations }\end{array}$ & 0.705 & 0.004 & 0.290 & 0.005 \\
\hline
\end{tabular}

${ }^{a}$ Following sequential Bonferroni correction for multiple tests (Rice 1989), none of the $\mathrm{p}$ values retains statistical significance.

${ }^{b}$ Subpopulations are abbreviated as shown in Fig. 3.

bly always existed in relatively small populations, subject to repeated loss of genetic variation through drift and/or inbreeding. In contrast, the more genetically variable Mediterranean monk seal (Gemmell et al. 1997) may have existed in much larger populations in the past, given the more continuous nature of the coastal habitat around the Mediterranean Sea.

We have no information on Hawaiian monk seal abundance before the species was subject to heavy hunting pressure in the last century, nor do we know the size or duration of the resulting population bottleneck, but fewer than 20 generations have passed since the likely low point in abundance of about 100 years ago ( 5 years is the youngest documented age at first reproduction in this species; Johanos et al. 1994). Given typical microsatellite mutation rates of about $10^{-5}$ per generation (Bruford \& Wayne 1993), little variation is likely to have been generated at these loci since the bottleneck. Unfortunately, there are no Hawaiian monk seal populations unaffected by nineteenth century hunting, and no closely related species with large, healthy populations to provide an estimate of "baseline" microsatellite variation in the monk seal.

\section{Heterozygote Deficit and Excess}

The smallest monk seal subpopulation at Kure Atoll was characterized by a low number of heterozygous individuals at all three loci (Fig. 3). Reduced heterozygosity due to random genetic drift is clearly indicated in this small population. Although no individual locus-subpopulation combination deviated significantly from Hardy-Weinberg
Table 3. Unbiased $R_{S T}$ and $N m$ estimates calculated using $R_{S T}$ CALC (Goodman 1997b) for microsatellite loci $\mathrm{Hg6.3}(n=108$ individuals), BG $(n=51)$, and Pv17 $(n=46)$ in the five principal subpopulations of the Hawaiian monk seal (abbreviated as in Fig. 3).*

\begin{tabular}{|c|c|c|c|c|c|}
\hline Populations & & Hg6.3 & $B G$ & $P v 17$ & $\begin{array}{c}3 \text { loci } \\
\text { combined }\end{array}$ \\
\hline \multirow[t]{3}{*}{ PHR $\times$ LIS } & $R_{S T}$ & -0.024 & -0.030 & 0.055 & 0.004 \\
\hline & $N m$ & ++ & ++ & 4.324 & 56.79 \\
\hline & $p$ & 0.915 & 0.382 & 0.156 & 0.194 \\
\hline \multirow[t]{3}{*}{$\mathrm{PHR} \times \mathrm{KUR}$} & $R_{S T}$ & 0.004 & -0.047 & $(0.280)$ & 0.094 \\
\hline & $N m$ & 58.90 & ++ & 0.643 & 2.422 \\
\hline & $p$ & 0.225 & 0.715 & 0.010 & 0.030 \\
\hline \multirow[t]{3}{*}{ PHR $\times$ LAY } & $R_{S T}$ & -0.005 & -0.047 & -0.028 & -0.029 \\
\hline & $N m$ & ++ & ++ & ++ & ++ \\
\hline & $p$ & 0.347 & 0.768 & 0.453 & 0.624 \\
\hline \multirow[t]{3}{*}{ PHR $\times$ FFS } & $R_{S T}$ & 0.085 & 0.064 & $(-0.017)$ & 0.042 \\
\hline & $N m$ & 2.675 & 3.662 & ++ & 5.690 \\
\hline & $p$ & 0.026 & 0.043 & 0.410 & 0.118 \\
\hline \multirow[t]{3}{*}{ LIS $\times$ KUR } & $R_{S T}$ & 0.015 & -0.047 & 0.050 & -0.001 \\
\hline & $N m$ & 16.67 & ++ & 4.716 & ++ \\
\hline & $p$ & 0.211 & 0.728 & 0.179 & 0.338 \\
\hline \multirow[t]{3}{*}{ LIS $\times$ LAY } & $R_{S T}$ & 0.004 & -0.003 & -0.025 & -0.009 \\
\hline & $N m$ & 60.59 & ++ & ++ & ++ \\
\hline & $p$ & 0.259 & 0.329 & 0.468 & 0.476 \\
\hline \multirow[t]{3}{*}{ LIS $\times$ FFS } & $R_{S T}$ & (0.079) & -0.011 & -0.039 & 0.016 \\
\hline & $N m$ & 2.907 & ++ & ++ & 14.94 \\
\hline & $p$ & 0.032 & 0.306 & 0.648 & 0.201 \\
\hline \multirow[t]{3}{*}{$\mathrm{KUR} \times \mathrm{LAY}$} & $R_{S T}$ & -0.024 & -0.031 & $(0.153)$ & 0.032 \\
\hline & $N m$ & ++ & ++ & 1.384 & 7.616 \\
\hline & $p$ & 0.825 & 0.590 & 0.057 & 0.233 \\
\hline \multirow[t]{3}{*}{$\mathrm{KUR} \times \mathrm{FFS}$} & $R_{S T}$ & $0.206^{\dagger}$ & 0.023 & 0.125 & 0.127 \\
\hline & $N m$ & 0.966 & 10.71 & 1.746 & 1.712 \\
\hline & $p$ & 0.002 & 0.262 & 0.085 & 0.023 \\
\hline \multirow[t]{3}{*}{$\mathrm{LAY} \times \mathrm{FFS}$} & $R_{S T}$ & $0.183^{\dagger}$ & 0.111 & $(-0.054)$ & 0.083 \\
\hline & $N m$ & 1.116 & 2.009 & ++ & 2.778 \\
\hline & $p$ & 0.002 & 0.096 & 0.927 & 0.071 \\
\hline \multirow[t]{3}{*}{ Overall } & $R_{S T}$ & $0.071^{\dagger}$ & -0.001 & 0.041 & 0.037 \\
\hline & $N m$ & 3.274 & ++ & 5.805 & 6.487 \\
\hline & $p$ & 0.002 & 0.405 & 0.163 & 0.036 \\
\hline
\end{tabular}

*The $\mathrm{p}$ values are based on 1000 permutations; values significant at the 0.05 level after sequential Bonferroni correction (Rice 1989) are marked with a dagger. Negative $\mathrm{R}_{\mathrm{ST}}$ values indicate that within-population variance in allele size is greater than between-populations variance and that the populations are panmictic, with $\mathrm{Nm}$ values too large to quantify $(++)$ with this approach (Goodman 1997b). Strongly discordant results from a single locus are enclosed in parentheses. Populations are abbreviated as in Fig. 3.

expectations (Appendix), when results from all three loci were pooled, the Kure population showed evidence of a heterozygote deficit. Although this deficit was not significant after application of the sequential Bonferroni correction for multiple tests (Rice 1989; Table 2), the trend observed within the Kure subpopulation indicates that mating may have occurred among close relatives at this site. Especially low genetic variability and possible inbreeding in the Kure subpopulation were also indicated by a previous study, in which a small sample of individuals presumed to be unrelated was shown to have a high level of DNA fingerprint band-sharing (73\%), and a single mtDNA control region haplotype was found in all 10 individuals (Kretzmann et al. 1997). 
Because Kure's population size has been small (fewer than 100 seals) over the last several generations (Ragen 1993; Gilmartin \& Eberhardt 1995), the probability of sampling of related animals was therefore highest at this site, and this may have contributed to the lack of heterozygosity observed. In fact, two known pairs of (at least) half-siblings were included in our Kure sample, each born to the same mother 3 years apart ( $T$. Johanos, personal communication). But many of our samples (including all of those from Pearl and Hermes Reef) were obtained from seals with unidentified mothers, and we are therefore uncertain about their relatedness. For this reason we cannot determine whether variability in the Kure sample was biased by the inclusion of more relatives than were found in our other samples.

Other potential explanations for the heterozygote deficit include the presence of null alleles (Pemberton et al. 1995) or a Wahlund effect resulting from the mixture of two populations at Kure Atoll (due to the addition of seals from French Frigate Shoals). The heterozygote deficit was confined to a single subpopulation (Table 2). Because all islands shared the same most common allele at all three loci (Fig. 3), it appears unlikely that a null allele would be present at substantial frequency in only a single population. Of the 20 pups sampled at Kure, 17 were known to be born to native Kure mothers, and 2 others were most likely of native origin ( $T$. Johanos, unpublished data). We therefore consider our samples from Kure to be representative of that site and believe that our results are not attributable to a Wahlund effect.

In marked contrast to the Kure sample, the Pearl and Hermes Reef population (also reduced to low numbers but currently larger and increasing; Ragen 1993) showed an apparent excess of heterozygous individuals at these microsatellite loci (Fig. 3). It is possible that differences in male mating success at these two sites contributed to the pattern observed. Because pupping and haulout at Kure have occurred primarily at one site since 1985 (Westlake \& Gilmartin 1990) and because the population remains small, a single male might have dominated the mating at this location each year or over a period of several years. It has likely been more difficult for one male to monopolize recent mating at Pearl and Hermes Reef, because more widely separated areas are used by a larger number of breeding females at this location (Westlake \& Gilmartin 1990).

\section{Subpopulation Differentiation}

The slight differences in allele frequencies among islands (Fig. 3) yielded an estimate of subpopulation differentiation over all loci and subpopulations of $R_{S T}=$ 0.037 (Table 3). Genetic structuring among all five monk seal breeding sites has not been demonstrated conclusively, particularly because the overall $R_{S T}$ value was attributable primarily to a single locus (Hg6.3), and because the pattern was not consistent across loci (Table 3). Similarly, the allelic goodness-of-fit test revealed a single significant result: French Frigate Shoals was differentiated from the other four islands at only one locus (Hg6.3).

In an analysis of genetic differentiation among harbor seal populations based on two of the same microsatellite loci, Goodman (1998) found that those populations were clearly genetically more variable and more differentiated from one another than were the monk seal populations. Loci BG and Hg6.3 showed seven to eight alleles in a sample of about 1000 harbor seals; the overall $R_{S T}$ value for the 12 populations was 0.181 (Goodman 1998). On the other hand, locus Hg6.3 showed six alleles in a sample of over 1000 grey seals but yielded an $F_{S T}$ value of 0.015 between two colonies of grey seals (from islands off the east and west coasts of Scotland; Allen et al. 1995). In our study of monk seals, the overall estimate of $F_{S T}$ based on this locus alone was 0.071 (same as $R_{S T}$; Table 3 ). This finding implies that less genetic exchange occured among the five monk seal subpopulations than between those two grey seal populations.

The 10 pairwise comparisons among islands revealed only a single convincing case of significant $R_{S T}$ value, between French Frigate Shoals and Kure Atoll (Table 3). These two subpopulations are located at the two extreme ends of the island chain (Fig. 1). These findings are quite different from previously reported estimates of subpopulation differentiation based on multilocus DNA fingerprinting of monk seals. The fingerprinting study was based on small sample sizes and compared only two pairs of adjacent islands, but it found significant differentiation between both pairs (Kretzmann et al. 1997). Although minisatellite DNA typically has mutation rates several orders of magnitude higher than microsatellite loci (Bruford \& Wayne 1993) and would therefore be expected to reveal more genetic differences, the DNA fingerprinting study could have overestimated interisland differentiation if samples from different sites varied in quality (Kretzmann et al. 1997).

The fact that the French Frigate Shoals subpopulation may be differentiated from Kure Atoll is significant because it served as the source population for rehabilitated juvenile seals released at Kure Atoll between 1985 and 1995 (Gerrodette \& Gilmartin 1990; Van Toorenburg et al. 1993). Therefore, continued translocations might eventually have the unintended consequence of genetic homogenization of the two subpopulations that appear to be differentiated at these microsatellite loci (although this conclusion is based primarily on results from a single locus; Table 3). Chesser (1983) advocated maintaining isolated populations of endangered species to preserve maximum genetic diversity overall, and crossmating among populations if inbreeding becomes problematic. But this recommendation was based on the assumption that alternative alleles will be preserved in separate sub- 
populations, which is not the case for the Hawaiian monk seal at these microsatellite loci. The allele frequency differences found in this study are unlikely to reflect long-term historical isolation of these populations, because most individuals from all islands shared an identical mtDNA control region sequence, and one rare mitochondrial haplotype was found at four of five major breeding sites (Kretzmann et al. 1997).

French Frigate Shoals and Kure Atoll might be considered separate management units (MUs) based on significant divergence in nuclear allele frequencies (Moritz 1999). But, limited mixing of such MUs may be desirable during augmentation of remnant populations that may suffer from inbreeding depression, as long as the translocated individuals can thrive in the new environment (Moritz 1999). Many of the females translocated to Kure have now successfully entered the breeding population and may have the potential to relieve inbreeding at this site. In any event, the translocations have had positive demographic effects (Gilmartin \& Eberhardt 1995), which are important given the declining survival of juvenile seals at French Frigate Shoals in recent years (Gilmartin \& Eberhardt 1995; Craig \& Ragen 1999) and the low reproductive rate of monk seal females (Johanos et al. 1994). The augmentation of the small Kure population represents a substantial demographic improvement, particularly because these translocated individuals were removed from French Frigate Shoals in emaciated condition, with little chance of survival at that site.

We recommend continued genetic monitoring of both the source and recipient populations to determine whether the population differentiation suggested by these microsatellite data can be confirmed. Based on our experience with three independent molecular marker systems, variation at individual minisatellite loci might be most useful for determining whether the offspring of translocated females from French Frigate Shoals differ genetically from the offspring of native Kure mothers. A comparison of reproductive success (pup production and survival) in these two groups of females now breeding at Kure, as well as females breeding at French Frigate Shoals, would provide some indication as to whether the translocated individuals suffer any decreased fitness as a result of this management action.

\section{Acknowledgments}

We gratefully acknowledge the invaluable assistance of many members of the monk seal team at the Honolulu Laboratory of the National Marine Fisheries Service, in collecting samples and providing essential background information, especially W. Gilmartin, T. Johanos, A. Sloan, and B. Becker. B. Antonelis, P. Dratch, and two anonymous reviewers made helpful comments on the manuscript. We also thank W. Rice and B. Amos for helpful discussion and D. Costa for enthusiastic support and assistance with financing this project. N.J.G. was supported by a grant from the Leverhulme Trust. Additional financial support was provided by National Science Foundation grants BSR 9107838 and DEB 9615178 to A.M.

\section{Literature Cited}

Allen, P. J., B. Amos, P. P. Pomeroy, and S. D. Twiss. 1995. Microsatellite variation in grey seals (Halichoerus grypus) shows evidence of genetic differentiation between two British breeding colonies. Molecular Ecology 4:653-662.

Bruford, M. W., and R. K. Wayne. 1993. Microsatellites and their application to population genetic studies. Current Opinion in Genetics and Development 3:939-943.

Carson, H. L., and D. A. Clague. 1995. Geology and biogeography of the Hawaiian islands. Pages 14-29 in W. L. Wagner and V. A. Funk, editors. Hawaiian biogeography: evolution on a hot spot archipelago. Smithsonian Institution Press, Washington, D.C.

Chesser, R. K. 1983. Isolation by distance: relationship to the management of genetic resources. Pages 66-77 in C. M. Schonewald-Cox, S. M. Chambers, B. MacBryde, and W. L. Thomas, editors. Genetics and conservation: a reference for managing wild animal and plant populations. Benjamin/Cummings, Menlo Park, California.

Coltman, D. W., W. D. Bowen, and J. M. Wright. 1996. PCR primers for harbour seal (Pboca vitulina concolour) microsatellites amplify polymorphic loci in other pinniped species. Molecular Ecology 5:161-163.

Craig, M. P., and T. J. Ragen. 1999. Body size, survival, and decline of juvenile Hawaiian monk seals, Monachus schauinslandi. Marine Mammal Science 15:786-809.

de Muizon, C. 1982. Phocid phylogeny and dispersal. Annals of the South African Museum 89:175-213.

Eldridge, M. D. B., et al. 1999. Unprecedented low levels of genetic variation and inbreeding depression in an island population of the black-footed rock-wallaby. Conservation Biology 13:531-541.

Ellegren, H., C. R. Primmer, and B. C. Sheldon. 1995. Microsatellite evolution: directionality or bias in locus selection? Nature Genetics 11:360-362.

Gemmell, N. J., P. J. Allen, S. J. Goodman, and J. Z. Reed. 1997. Interspecific microsatellite markers for the study of pinniped populations. Molecular Ecology 6:661-666.

Gerrodette, T., and W. G. Gilmartin. 1990. Demographic consequences of changed pupping and hauling sites of the Hawaiian monk seal. Conservation Biology 4:423-430.

Gilmartin, W. G., and L. L. Eberhardt. 1995. Status of the Hawaiian monk seal (Monachus schauinslandi) population. Canadian Journal of Zoology 73:1185-1190.

Goldstein, D. B., and D. D. Pollock. 1997. Launching microsatellites: a review of mutation processes and methods of phylogenetic inference. Journal of Heredity 88:35-342.

Goodman, S. J. 1997a. Dinucleotide repeat polymorphisms at seven anonymous microsatellite loci cloned from the European Harbour seal (Pboca vitulina vitulina). Animal Genetics 28:310-311.

Goodman, S. J. 1997b. $\mathrm{R}_{\mathrm{ST}}$ Calc: a collection of computer programs for calculating estimates of genetic differentiation from microsatellite data and determining their significance. Molecular Ecology 6:881-885.

Goodman, S. J. 1998. Patterns of extensive genetic differentiation and variation among European harbor seals (Pboca vitulina vitulina) revealed using microsatellite DNA polymorphisms. Molecular Biology and Evolution 15:104-118.

Goudet, J., M. Raymond, T. de Meeüs, and F. Rousset. 1996. Testing differentiation in diploid populations. Genetics 144:1933-1940.

Guo, S. W., and E. A. Thompson. 1992. Performing the exact test of Hardy-Weinberg proportion for multiple alleles. Biometrics 48: 361-372. 
Holm, L.-E., M. C. Forchhammer, and J. J. Boomsma. 1999. Low genetic variation in muskoxen (Ovibos moschatus) from western Greenland using microsatellites. Molecular Ecology 8:675-679.

Johanos, T. C., B. L. Becker, and T. J. Ragen. 1994. Annual reproductive cycle of the female Hawaiian monk seal. Marine Mammal Science 10:13-30.

Johnson, A. M., and E. Kridler. 1983. Interisland movements of the Hawaiian monk seal. 'Elepaio 44:43-45.

Johnson, A. M., R. L. DeLong, C. H. Fiscus, and K. W. Kenyon. 1982. Population status of the Hawaiian monk seal (Monachus schauinslandi), 1978. Journal of Mammalogy 63:415-421.

Kenyon, K. W. 1972. Man versus the monk seal. Journal of Mammalogy 53:687-696.

Kenyon, K. W., and D. W. Rice. 1959. Life history of the Hawaiian monk seal. Pacific Science 13:215-252.

Kretzmann, M. B., et al. 1997. Low genetic variability in the Hawaiian monk seal. Conservation Biology 11:482-490.

Louis, E. J., and E. R. Dempster. 1987. An exact test for Hardy-Weinberg and multiple alleles. Biometrics 43:805-811.

Maniatis, T., J. Sambrook, and E. F. Fritsch. 1989. Molecular cloning: a laboratory manual. 2nd ed. Cold Spring Harbor Laboratory, Cold Spring Harbor, NY.

Moritz, C. 1999. Conservation units and translocations: strategies for conserving evolutionary processes. Hereditas 130:217-228.

Paetkau, D., and C. Strobeck. 1994. Microsatellite analysis of genetic variation in black bear populations. Molecular Ecology 3:489-495.

Pemberton, J. M., J. Slate, D. R. Bancroft, and J. A. Barrett. 1995. Nonamplifying alleles at microsatellite loci: a caution for parentage and population studies. Molecular Ecology 4:249-252.

Petit, E., S. Aulagnier, D. Vaiman, C. Bouissou, and B. Crouau-Roy. 1997. Microsatellite variation in an introduced mouflon population. Journal of Heredity 88:517-520

Ragen, T. J. 1993. Status of the Hawaiian monk seal in 1992. NOAA-
NMFS report H-93-05. Southwest Fisheries Science Center Honolulu Laboratory, Honolulu.

Raymond, M., and F. Rousset. 1995. GENEPOP (version 1.2): population genetics software for exact tests and ecumenicism. Journal of Heredity 86:248-249.

Rice, W. R. 1989. Analyzing tables of statistical tests. Evolution 43: 223-225.

Schwengel, D. A., A. E. Jedlicka, E. J. Nanthakumar, J. L. Weber, and R. C. Levitt. 1994. Comparison of fluorescence-based semi-automated genotyping of multiple microsatellite loci with autoradiographic techniques. Genomics 22:46-54.

Slatkin, M. 1995. A measure of population subdivision based on microsatellite allele frequencies. Genetics 139:457-462.

Sokal, R. R., and F. J. Rohlf. 1995. Biometry: the principles and practice of statistics in biological research. 3rd edition. W. H. Freeman and Company, New York.

Tautz, D. 1989. Hypervariability of simple sequences as a general source for polymorphic DNA markers. Nucleic Acids Research 17: 6463-6471.

Taylor, A. C., W. B. Sherwin, and R. K. Wayne. 1994. Genetic variation of microsatellite loci in a bottlenecked species: the northern hairynosed wombat Lasiorbinus kreffii. Molecular Ecology 3:277-290.

Van Toorenburg, R. A., W. G. Gilmartin, and J. R. Henderson. 1993. Composition of the Hawaiian monk seal population at Kure Atoll, 1990. Pacific Science 47:211-214.

Weber, J. L., and P. E. May. 1989. Abundant class of human DNA polymorphisms which can be typed using the polymerase chain reaction. American Journal of Human Genetics 44:388-396.

Weir, B. S., and C. C. Cockerham. 1984. Estimating F-statistics for the analysis of population structure. Evolution 38:1358-1370.

Westlake, R. L., and W. G. Gilmartin. 1990. Hawaiian monk seal pupping locations in the northwestern Hawaiian islands. Pacific Science 44:366-383.

\section{Appendix}

Allele frequencies (AF) for each locus (allele sizes given in base pairs) and population, with estimates of heterozygosity and $p$ (probability of error when rejecting Hardy-Weinberg equilibrium) calculated according to Louis and Dempster (1987) with GENEPOP (version 2, Raymond \& Rousset 1995).

\begin{tabular}{|c|c|c|c|c|c|}
\hline \multirow[b]{2}{*}{ Locus } & \multicolumn{5}{|c|}{ Population* $^{*}$} \\
\hline & $K U R$ & $P H R$ & $L I S$ & $L A Y$ & $F F S$ \\
\hline \multicolumn{6}{|l|}{ Pv17 } \\
\hline no. of individuals & 10 & 7 & 10 & 10 & 9 \\
\hline AF 144/146 & $0.95 / 0.05$ & $0.57 / 0.43$ & $0.80 / 0.20$ & $0.70 / 0.30$ & $0.72 / 0.28$ \\
\hline$H_{o} / H_{e}$ & $0.10 / 0.10$ & $0.57 / 0.53$ & $0.40 / 0.34$ & $0.40 / 0.44$ & $0.33 / 0.43$ \\
\hline$p$ & - & 1.00 & 1.00 & 1.00 & 1.00 \\
\hline \multicolumn{6}{|l|}{ Hg6.3 } \\
\hline no. of individuals & 20 & 18 & 25 & 21 & 24 \\
\hline AF $230 / 240$ & $0.85 / 0.15$ & $0.75 / 0.25$ & $0.74 / 0.26$ & $0.83 / 0.17$ & $0.52 / 0.48$ \\
\hline$H_{o} / H_{e}$ & $0.20 / 0.26$ & $0.50 / 0.39$ & $0.44 / 0.39$ & $0.33 / 0.29$ & $0.46 / 0.51$ \\
\hline$p$ & 0.35 & 0.52 & 1.00 & 1.00 & 0.70 \\
\hline \multicolumn{6}{|l|}{$\mathrm{BG}$} \\
\hline no. of individuals & 10 & 10 & 10 & 10 & 11 \\
\hline AF 259/284 & $0.35 / 0.65$ & $0.40 / 0.60$ & $0.30 / 0.70$ & $0.45 / 0.55$ & $0.18 / 0.82$ \\
\hline$H_{o} / H_{e}$ & $0.30 / 0.48$ & $0.80 / 0.51$ & $0.60 / 0.44$ & $0.30 / 0.52$ & $0.36 / 0.31$ \\
\hline$p$ & 0.48 & 0.17 & 0.48 & 0.25 & 1.00 \\
\hline
\end{tabular}

*Populations are abbreviated as in Fig. 3. 